\title{
Design of a Measuring System Suitable for Measuring the Electromagnetic and Dynamic Characteristics of Electric Motors
}

\author{
Attila SZÁNTÓ, ${ }^{1}$ Roland DÉCSEI, ${ }^{2}$ Márton KUJBUS, ${ }^{3}$ Levente FEJES, ${ }^{4}$ Nóra PAPCSÁK, ${ }^{5}$ \\ Gusztáv Áron SZIKI ${ }^{6}$ \\ University of Debrecen, Faculty of Engineering, Debrecen, Hungary \\ ${ }^{1}$ szanto.attila@eng.unideb.hu \\ ${ }^{2}$ roland.decsei@gmail.com \\ ${ }^{3}$ kujbusmarci@gmail.com \\ ${ }^{4}$ leventefejes1@gmail.com \\ ${ }^{5}$ papcsak.nora@gmail.com \\ ${ }^{6}$ szikig@eng.unideb.hu
}

\begin{abstract}
Thanks to technological development, and the more and more strict environmental regulations, electric and hybrid vehicles are playing an increasingly important role in road transport. An important part of these vehicles is the electric motor, which has several different types that are applied in modern vehicles. To perform the simulation of the motors, it is important to measure their basic electromagnetic and dynamic parameters, since they are usually not provided by the manufacturers. For the above measurements a complex measuring system is needed. This motor test bench is also suitable for the static and dynamic testing of different types of electric motors. In this publication the layout of our own developed test bench is presented.
\end{abstract}

Keywords: electric motor, measuring system, motor test bench, simulation.

\section{Introduction}

Nowadays, various alternative propulsion vehicles are becoming increasingly widespread in road transport. Among these vehicles, those with electric and hybrid drives are the most widespread, thanks to the rapid development of batteries and electrical and hybrid systems. [1] The electric motor is an important part of these systems, thus its study plays an important role in industrial and academic research.

Several research groups at the Faculty of Engineering of the University of Debrecen deal with the study, modelling and simulation of different types of modern vehicle drives. The gained experience during the last few years can be utilized in university competitions for alternative propulsion vehicles. For more conscious design and rac- ing, a vehicle dynamics simulation program was developed in Matlab/Simulink [2, 3] previously, which generates the dynamic functions of a vehicle from its technical characteristics and data. Using the above program, we can optimize the technical parameters of a vehicle, or its power-train, to a given competition task.

An important part of the simulation program is the simulation of the drive system of the vehicle, including the electric motor. [4-7] In order to run the simulation, it is necessary to know the basic electromagnetic and dynamic characteristics of the electric motor. In most cases these data are not provided by the manufacturers, so they need to be measured. For this purpose, we have developed a measuring system, which is suitable for determining the electromagnetic and dynamic 
characteristics of various types of electric motors, and additionally testing them.

In this publication we present the layout, the different components and operation of the measuring system we have developed.

\section{Schematic diagram of the measuring system}

A simplified schematic diagram of the planned measuring system is illustrated in Figure 1. The components that have been already installed and tested are briefly described in section 3 .

\section{Description of the existing compo- nents of the measuring system}

The measuring system has several components that are essential for performing measurements on different types of electric motors at the required quality and accuracy level. In addition, each component must meet several well-defined technical requirements. In the following, we describe the existing and tested components of the system and give a brief technical description. Additionally, we present some of the technical solutions we have applied

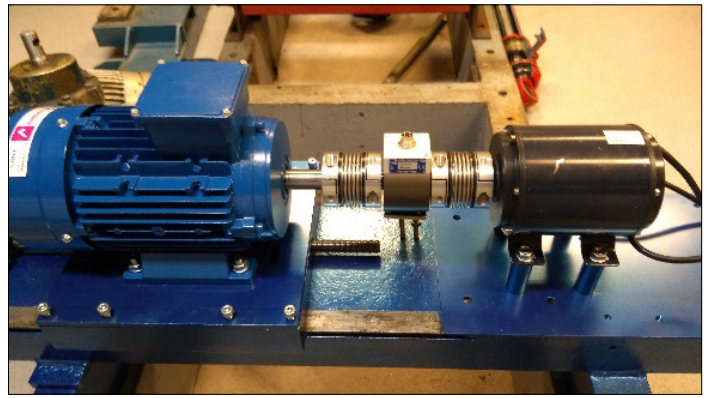

Figure 2. The motor bench with the load and tested motor on it.

\subsection{Rigid, adjustable bench for mounting different types of electric motors}

To be able to build the measuring system, first of all, we need a rigid bench on which the load and tested motor can be mounted (Figure 2). The radial adjustment of the tested motor is ensured by mounting adapters made for each motor individually. Axial (as well as a small horizontal and vertical) adjustment of the load motor is also possible. Uniaxial precision is set applying a dial gauge as well as a laser axis adjuster .

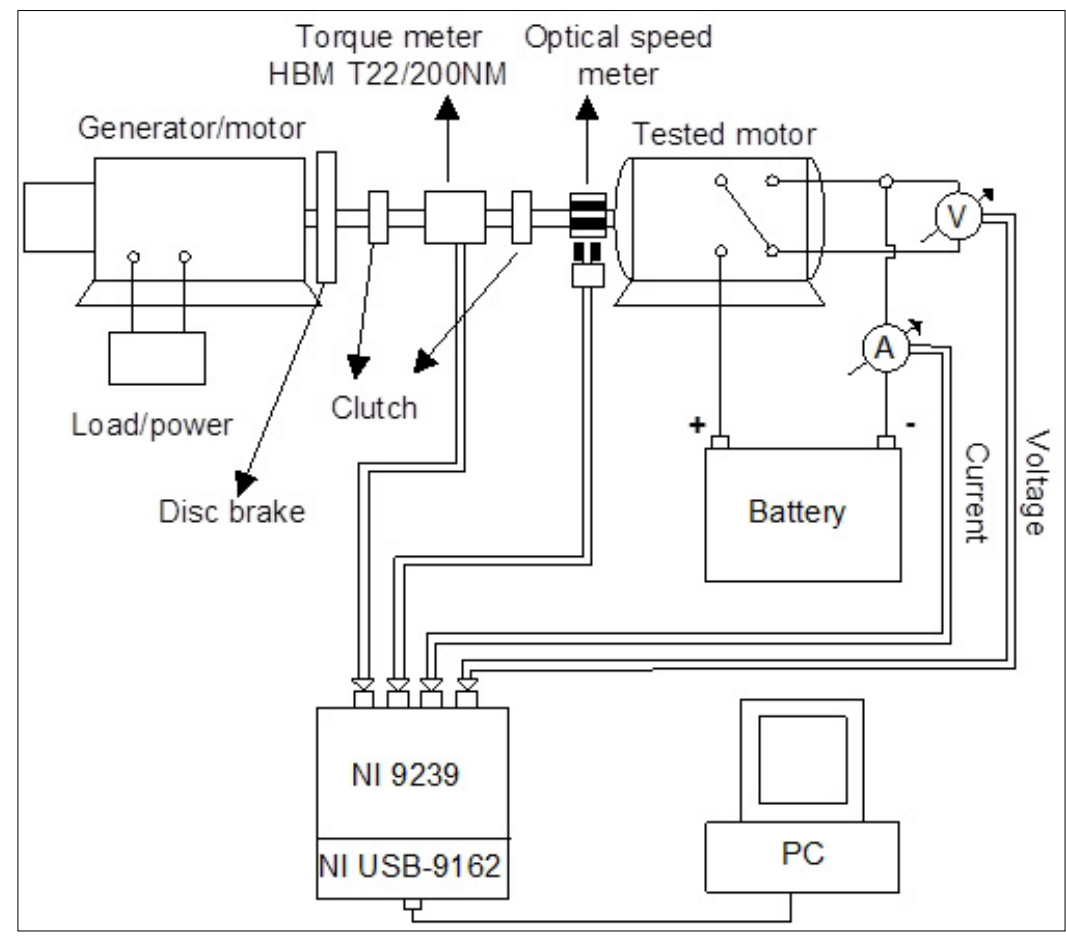

Figure 1. Schematic diagram of the measuring system. 
For mounting a flanged motor, a custom-made adapter is applied, that can be attached to the bench securely. Thus, both foot and flange mounted motors can be tested with our measuring system.

\subsection{Data acquisition card}

The data acquisition card is a NI 9239 highspeed analog-digital (AD) module manufactured by National Instruments (Figure 3), which is connected to the data recording laptop through an NI USB-9162 USB adapter. It measures an analog voltage signal in the $0-10$ [V] range on 4 earth-independent channels. The card is capable of sampling at 24-bit resolution at a sampling frequency of $50 \mathrm{kHz}$. This provides us a sufficient amount of data for any measurement tasks we are planning.

For the measurements we have created a self-developed data recording program in NI LabVIEW. The main parameters of data recording can be specified in the program, and the value of voltage signal in each channel can be monitored in real time. Thus, the measurement of each physical quantity is realised as the measurement of a voltage signal.

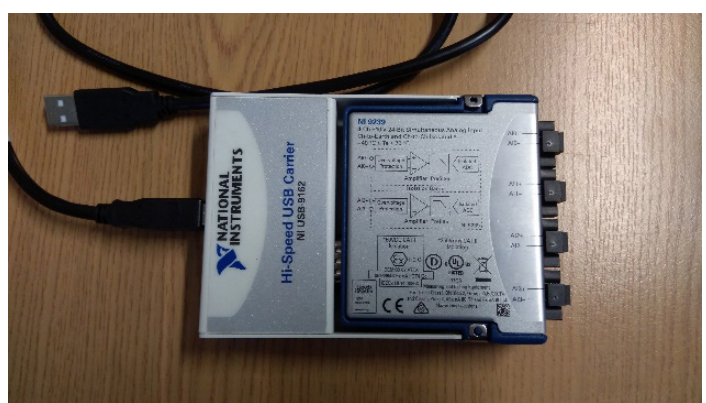

Figure 3. NI 9239 analog-digital module with NI USB-9162 USB adapter.

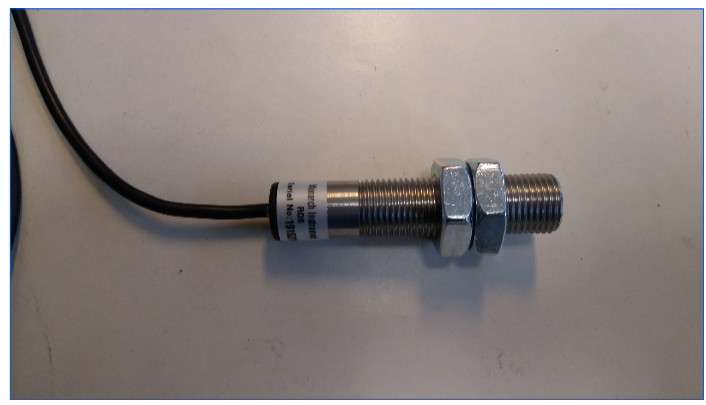

Figure 4. The optical LED sensor.

\subsection{Optical speed meter}

To measure the motor speed, a reflection optical LED sensor (type: ROS-P, Monarch Instrument, Figure 4) is used. It operates from a $6 \mathrm{~V} \mathrm{DC}$ power supply and provides a 6 or $0 \mathrm{~V}$ output voltage signal depending on whether light is reflected from the rotating object to the sensor, or not. To be able to do this, reflective strips are fixed to the circumference of the rotating object (e.g. to the shaft of the motor). The speed can be calculated from the number of these strips, and the number of voltage signals.

\subsection{Torque measurement}

For torque measurement a HBM T22/200 rotary shaft torque meter (Figure 5) is applied. We can connect it to the load and tested motor with clutches of different size, depending on the possible maximum value of applied torque. The torque meter has a measuring range of 0-200 $\mathrm{Nm}$, and an output voltage signal in the $0-10 \mathrm{~V}$ range, which is proportional to the measured torque.

\subsection{Current intensity and voltage measure- ment}

The intensity of electric current flowing through the motor is measured as a voltage drop across a shunt resistor with a resistance of $0.0006 \Omega$. The terminal voltage of the battery, since it is bigger than the maximum allowed input voltage of the NI 9239 device (10V), is measured applying a voltage divider with a ratio of 1:11.

\section{Summary}

In this publication the layout and main elements of our measuring system for the experimental study of electric motors is presented. Applying the system, the electromagnetic and dynamic characteristics of different types of electric motors can be measured. Additionally, static and dynamic test measurements can be performed on

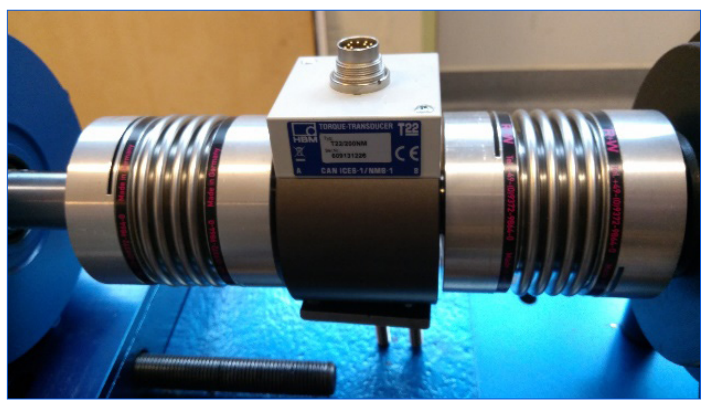

Figure 5. The rotary shaft torque meter with clutches. 
the motors. When the system is built on, we intend to calibrate its different units. Subsequently we intend to perform measurements on the BLDC motor, which is shown in Figure 2, to determine its electromagnetic and dynamic characteristics, which serve as input parameters of our simulation program. Finally, we are planning to perform test measurements on the same motor.

\section{Acknowledgement}

Supported by the ÚNKP-20-3 new national excellence program of the ministry for innovation and technology from the source of the national research, development and innovation fund.

\section{References}

[1] Szántó A., Szíki G. Á.: Review of Modern Vehicle Powertrains and Their Modelling and Simulation in MATLAB/Simulink. International Journal of Engineering And Management Sciences / Müszaki és Menedzsment Tudományi Közlemények 5/2. (2020) 232-250.

[2] Szántó Attila et. al.: Jármü dinamikai szimuláció és optimalizáció. Müszaki Tudományos Közlemények, 9. (2018) 219-222.

https://doi.org/10.33895/mtk-2018.09.50
[3] Szántó A., Szíki G. Á., Hajdu S.: Dynamics Simulation of a Prototype Race Car Driven by Series Wound DC Motor in Matlab-Simulink. Acta Polytechnica Hungarica, 17/4. (2020) 103-122. https://doi.org/10.12700/APH.17.4.2020.4.6

[4] Szíki G. Á., Sarvajcz K., Kiss J., Gál,T., Szántó A., Gábora A., Husi G.: Experimental Investigation of a Series Wound Dc Motor for Modeling Purpose in Electric Vehicles and Mechatronics Systems. In: Measurement, 109. (2017) 111-118.

https://doi.org/10.1016/j.measurement.2017.05.055

[5] Hadziselimovic M., laznik M., Štumberger B., Zagradišnik I.: Magnetically Nonlinear Dynamic Model of a Series Wound DC Motor. Przeglad Elektrotechniczny (Electrical Review), R. $87 \mathrm{nr}$ $12 \mathrm{~b} / 2011$.

[6] Szíki G. Á., Szántó A., Mankovits T.: Dynamic Modelling and Simulation of a Prototype Race Car in MATLAB/Simulink Applying Different Types of Electric Motors. International Review Of Applied Sciences And Engineering, 2020. 1-7. https://doi.org/10.1556/1848.2020.00145

[7] Szántó Attila, Szántó András, Sziki G. Á.: Review of the Modelling Methods of Series Wound DC motors. Műszaki Tudományos Közlemények, 13. (2020)166-169.

https://doi.org/10.33894/mtk-2020.13.31 